\title{
Planning Registrar and Senior Registrar Training in Mental Handicap
}

\author{
D. A. SPencer, Consultant Psychiatrist, Meanwood Park Hospital, Leeds
}

The development of more rotational training schemes in psychiatry for registrars and senior registrars is introducing more trainees to mental handicap. Generally, however, mental handicap is not regarded by the trainees as the most interesting or highly-prized assignment; because of the nature of the patients, the long-stay hospitals involved and unfamiliarity with its problems, mental handicap lacks the appeal of some other subspecialties in psychiatry.

It is all the more important, therefore, for the consultant staff and the clinical tutors to study how the attachments to mental handicap can be made more attractive and more useful. Senior registrars in psychiatry who intend to practise overseas in countries where they will have to deal with mental handicap as part of a general psychiatric service already have the motivation to gain this experience in Britain.

Trainees accustomed to busy general hospitals need to be made aware of the differences they will meet in mental handicap practice. They will not see the number of new patients they do in the acute psychiatric unit. The cases they see are likely to be more complicated, and to demand more time per case. Not only medical and psychiatric, but psychological, social, educational and occupational assessments are often required, that is, a 'multidisciplinary' approach. In mental handicap, the specialist's involvement with a patient is less episodic and is often long-term. This means that the registrar spending only six months in mental handicap is at a disadvantage in following through cases. The senior registrar, who spends longer, does not have this difficulty.

In relating to the staff in mental handicap hospitals the doctor can best help them by listening to them and by seeking to understand their problems. Long-stay hospitals for mental handicap have large legacies of patients from the past. These cases provide a reservoir of captive 'clinical material' for teaching and study. Nearly every long-stay patient will demonstrate some medical, psychiatric, social and psychological problems. A hospital for mental handicap is a community where a number of people are living together. The doctor coming into the hospital should try to identify with it and to participate in the community as a whole. This may involve showing an interest in activities which are not exclusively medical, such as rehabilitational, educational and recreational programmes.

It is necessary for the trainee to appreciate that the same standards of medical practice and medical ethics are applied to the mentally handicapped patient as to the normal person. Because mentally handicapped patients are often unable to understand treatment, to give consent to procedures, or to complain, special care is needed in their management. The trainee has to be alerted to the need to pay careful attention to accidents, incidents and mishaps to mentally handicapped patients which need to be fully reported and officially handled without delay.

Mental handicap, perhaps more than many other fields of medical work, is what the doctor makes it, and this reflects the motivation and enthusiasm of the doctor. The trainee's motivation will be encouraged by carefully planned, flexible and clearly structured programmes of training specially devised for the six months registrar period or the longer senior registrar assignment.

\section{Syllabus}

One approach is to list the topics which the trainee should cover and to consider how the necessary instruction and experience are to be achieved. A table can then be drawn up as shown below.

The topics to be covered will vary with the trainee, whether registrar or senior registrar, and the doctor's previous experience. Examples of topics could include case taking and presentation, out-patient consultation, case con-

TABLE: Instruction and experience

\begin{tabular}{lllll}
\hline Topics to be covered & Reading by trainee & $\begin{array}{l}\text { Practical work by } \\
\text { trainee under } \\
\text { consultant supervision }\end{array}$ & $\begin{array}{l}\text { Tutorial instruction of } \\
\text { trainee by consultant } \\
\text { and clinical tutor }\end{array}$ & $\begin{array}{l}\text { Demonstrations labora- } \\
\text { tory work and visits for } \\
\text { trainees to attend }\end{array}$ \\
\hline $\begin{array}{l}\text { E.g., cerebral palsy in } \\
\text { relation to mental } \\
\text { handicap }\end{array}$ & $\begin{array}{l}\text { Reference to reading } \\
\text { lists published by } \\
\text { Royal College of } \\
\text { Psychiatrists }\end{array}$ & $\begin{array}{l}\text { Case taking and } \\
\text { clinical examinations }\end{array}$ & $\begin{array}{l}\text { Discussion } \\
\text { trainee/tutor }\end{array}$ & $\begin{array}{l}\text { Visit to children's } \\
\text { assessment centres and } \\
\text { paediatricians ward } \\
\text { round }\end{array}$ \\
\hline
\end{tabular}


ference, medical disorders causing mental handicap, epilepsy, cerebral palsy and neurological disorders, chromosomal abnormalities and dermatoglyphs, biochemical abnormalities and screening, the psychiatry of mental handicap including family psychiatry, behaviour and conduct disorders, visual and hearing defects, speech and communication defects, problems of elderly mentally handicapped people, sexual problems in mentally handicapped people, rehabilitation, community placement and community services, visits to prisons and remand centres and preparation of reports for courts.

\section{Timetable}

Each trainee should prepare a timetable of his work for discussion and approval. This should be reviewed and updated as necessary when changes occur in the programme. The timetable should specify in-patient work such as ward rounds and case conferences, out-patient work, visits to facilities in the community, and times regularly spent on postgraduate training, private study and research. The trainee can help himself and his tutors by keeping a record of training in which he can note any special experience, for example, a visit to a Special Hospital.

\section{Parliamentary News}

\section{The Bill in the Commons}

The Second Reading debate on the Mental Health (Amendment) Bill took place in the House of Commons on 22 March, and the Bill was then committed to a Special Standing Committee. The Government speakers were the new Secretary of State, Mr Norman Fowler, and the new Minister for Health, Mr Kenneth Clarke, who wound up the debate. The speeches were on much the same lines as those of Government spokesmen in the Lords; criticisms from other speakers mainly concerned resources, legal representation at Tribunals and after-care. Mrs G. Dunwoody led for the Opposition, and a gratifying feature of her speech was her concern about the effects of the Bill's provisions on hospital staffs; she quoted the views of psychiatrists at the
Maudsley on the difficulties resulting from the inclusion of 'medication' in the clauses dealing with 'imposed' treatment.

\section{Action by the College}

A letter from the President explaining the views and action taken on the Bill has been sent to all members resident in Britain. The College is objecting to the 'impaired' clause and the exclusion of mental handicap from the Bill, mainly on the ground that the present protection afforded to patients against ill-treatment, etc, may be lost. The College is also pressing for the exclusion of medication from the clause concerning compulsory treatment. 